\title{
Evaluación del cloruro de sodio, eugenol y zeolita en el confinamiento de Ancistrus triradiatus
}

\author{
Evaluation of the use of sodium chloride, eugenol, \\ and zeolite in confinement of Ancistrus triradiatus
}

\section{Avaliação decloreto de sódio, o eugenol ezeolite em transporte Ancistrus triradiatus}

\author{
Wilson F. Ramírez-Duarte ${ }^{1}$, Carolina Pineda-Quiroga ${ }^{2}$, Nhora Martínez - Rueda ${ }^{3}$, \\ Pedro R. Eslava-Mocha ${ }^{4}$
}

MVZ, Research Group on Health of Aquatic Organisms - Instituto de Acuicultura de los Llanos, Universidad de los Llanos Zootecnista, Ejercicio particular

Estadistica, MSc, Departament of Science for Animal Production, School of Veterinary Medicine and Zootechny, National University of Colombia. Bogotá, Colombia.

4 MV, MSc, Research Group on Health of Aquatic Organisms - Instituto de Acuicultura de los Llanos, Universidad de los Llanos

Email: wramirezduarte@gmail.com

Recibido: octubre 10 de $2012 \quad$ Aprobado: mayo 07 de 2013

\begin{abstract}
Resumen
Se evaluó el uso de cloruro de sodio ( 1 y 2 g/L), eugenol ( 0.1 y $0.5 \mathrm{mg} / \mathrm{L})$, y zeolita ( $7 \mathrm{~g} / \mathrm{L}$ en confinamiento de $12 \mathrm{~h}$ y 10 $\mathrm{g} / \mathrm{L}$ en el de $48 \mathrm{~h}$ ), así como de las mezclas de cloruro de sodio más eugenol ( $1 \mathrm{~g} / \mathrm{L}$ y0.5 mg/L, respectivamente) y eugenol más zeolita ( $0.5 \mathrm{mg} / \mathrm{L}$ y 7 o $10 \mathrm{~g} / \mathrm{L}$, respectivamente) en confinamiento de Ancistrus triradiatus durante periodos de 12 y 48 h. Se midieron los parámetros de calidad del agua, oxígeno disuelto, $\mathrm{pH}$, temperatura, conductividad y concentraciones de amoniaco total, amonio no ionizado y nitrito. La concentración de glucosa en sangre fue medida antes de iniciar el confinamiento y a las 0,24 y 48 horas después de terminado dicho confinamiento. También se realizó una prueba de resistencia al estrés al finalizar el periodo de confinamiento mediante la exposición de peces a una solución salina hiperosmótica durante $1 \mathrm{~h}$, en la cual se registró el número de peces que mantenía el eje de nado a intervalos de 5 min; se registró la mortalidad al finalizar los periodos de confinamiento (12 y 48 horas) y la mortalidad acumulada durante los 7 días siguientes. El uso de 1 y $2 \mathrm{~g} / \mathrm{L}$ de cloruro de sodio en el confinamiento de $A$. triradiatus durante periodos de $12 \mathrm{~h}$ y de $1 \mathrm{~g} / \mathrm{L}$ durante periodos de $48 \mathrm{~h}$ incrementó la resistencia al estrés y redujo la mortalidad de los animales. El uso de eugenol o zeolita no mejoró la resistencia al estrés ni contribuyó a la reducción de la mortalidad de los animales, mientras que la exposición a las mezclas de sal más eugenol y de eugenol más zeolita incrementó la mortalidad, por lo que el uso de estas mezclas no es recomendado en operaciones de confinamiento de $A$. triradiatus.
\end{abstract}

Palabras clave: Aceite de clavo, clinoptilolita, Loricariidae, sal, transporte de peces.

\section{Abstract}

The use of sodium chloride ( 1 and $2 \mathrm{~g} / \mathrm{L}$ ), eugenol $(0.1$ and $0.5 \mathrm{mg} / \mathrm{L})$, and zeolite (clinoptilolite, $7 \mathrm{~g} / \mathrm{L}$ for $12 \mathrm{~h}$ and $10 \mathrm{~g} / \mathrm{L}$ for $48 \mathrm{~h}$ of confinement), and also mixtures of salt plus eugenol $(1 \mathrm{~g} / \mathrm{L}$ and $0.5 \mathrm{mg} / \mathrm{L}$, respectively) and eugenol plus zeolite 
$(0.5 \mathrm{mg} / \mathrm{L}$ and 7 or $10 \mathrm{~g} / \mathrm{L}$, respectively) were evaluated in the confinement of Ancistrus triradiatus for 12 and $48 \mathrm{~h}$. Water parameters as concentration of dissolved oxygen, $\mathrm{pH}$, temperature, conductivity, and concentrations of total ammonia, non-ionized ammonia and nitrite were monitored. The blood glucose concentration was measured before the confinement started and at 0, 24, and 48 hours after the confinement period finished. A stress resistance test was conducted right after the confinement time was completed by exposing the fish to a hyperosmotic saline solution for one hour, recording the number of fish that maintained the swimming axis at intervals of 5 minutes. The mortality at the end of both confinement periods (12 and 48 hours), and its cumulative percentage rate during the following 7 days were also recorded. The use of sodium chloride 1 and $2 \mathrm{~g} / \mathrm{L}$ in confinement times of $12 \mathrm{~h}$, and $1 \mathrm{~g} / \mathrm{L}$ in confinement time of 48 hours increased the resistance to confinement-induced stress, and reduced mortality of the animals. The use of eugenol and zeolite did not improve the response to the stress, nor contribute to the reduction of mortality of the animals, while exposure to the mixtures of salt plus eugenol and eugenol plus zeolite increased the mortality so they are not recommended in the confinement of A. triradiatus.

Keywords: Clove oil, clinoptilolite, fish transport, Loricariidae, salt.

\begin{abstract}
Resumo
Foi avaliada a utilização de cloreto de sódio ( 1 e 2 g/L), eugenol ( 0.1 e $0.5 \mathrm{mg} / \mathrm{L})$ e zeolita (7 g/L para $12 \mathrm{~h}$ de confinamentoe $10 \mathrm{~g} / \mathrm{L} \mathrm{em} 48 \mathrm{~h}$ ) e misturas de cloreto de sódio e eugenol (1 g/L e0.5 mg/ L, respectivamente) e eugenol mais zeolita (0,5 mg/L, 7 ou $10 \mathrm{~g} / \mathrm{L}$, respectivamente) para confinamento de Ancistrus triradiatus por períodos de 12 e $48 \mathrm{~h}$. Parâmetros de qualidade de água foram medidos: concentração de oxigênio dissolvido, $\mathrm{pH}$, temperatura, condutividade e concentração de amônia total e não ionizada e nitrito. A concentração de glicose no sangue foi medida antes e 0, 24 e 48 horas após a conclusão do período de confinamento. Um teste de estresse foi realizado no final do período de confinamento, expondo os peixes a uma salina hiperosmótica durante $1 \mathrm{~h}$, sendo registrado o número de peixes que manteve o eixo de natação em intervalos de $5 \mathrm{~min}$. Da mesma forma, a mortalidade foi registrada no final dos períodos de confinamento (12 e 48 horas), bem como o percentual acumulado nos 7 dias seguintes. A utilização de 1 e 2 g/L de cloreto de sódio no confinamento de A.triradiatusdurante $12 \mathrm{~h}$, e $1 \mathrm{~g} / \mathrm{L}$ a $48 \mathrm{~h}$ aumentou a resistência ao estresse e reduziu a mortalidade dos animais. O uso de zeolita ou eugenol não melhorou a resistência ao estressenem contribuiu para a redução da mortalidade dos animais, enquanto que a exposição a misturas de sal e eugenol e de eugenol e zeolita aumentou a mortalidade, de modo que o uso dessas misturas não é recomendado para o confinamento de A. triradiatus.
\end{abstract}

Palavras chave: Óleo de cravo, clinoptilolita, transporte de peixes, Loricariidae, sal.

\section{Introduction}

In Colombia, the harvesting of ornamental fish for export dates from the 1950's, and despite the commercial and social importance of the activity, the actual biological and handling knowledge is scarce (ManceraRodriguez and Alvarez-León,2008).

Xenocara, Ancistrus triradiatus (Eigenmann, 1918), is an ornamental armored catfish native to the Orinoco basin that belongs to the Loricaridae family. This family is the second in the number of ornamental species of commercial interest, and consisted of $20 \%$ of the total number of specimens exported from Colombia in 2009 (MADR and CCl, 2010).In spite of its importance, few studies exist about culture and reproduction of this species. Collazos-Lasso and Arias-Castellanos (2009) showed that its reproduction is possible and easy in captivity; currently, some fisheries in Colombia started the culture of $A$. triradiatus and other species of Loricaridae.

Routine activities in aquaculture, such as seining, handling and confinement, usual during shipment, are common factors of stress that threaten fish health and survival (Barton et al., 2000). A variety of techni- ques have been developed to mitigate the negative effects of these procedures. To improve the transport conditions of live fish, and increase their survival rate, various practices have been implemented, such as feeding management (Pan et al., 2010), use of loading densities appropriate to the species (Gomes et al., 2003a, 2003b;Urbinatiet al., 2004), reduction of water temperature (Golombieski et al., 2003; Lim et al., 2003), and addition of salt (Carneiro and Urbinati, 2001; Gomes et al., 2003a), anesthetics (Iversenet al., 2009; Pramodet al., 2010), and ion exchange resins to the water (Singh et al., 2004), and also the use of probiotics (Gomes et al., 2009).

Anesthetics are used in low concentrations to reduce fish metabolic rate through transport, which results in lower oxygen consumption, with consequent reduction of ammonia and $\mathrm{CO}_{2}$ production, all factors favoring survival during and after transport (Hoskonen and Pirhonen, 2004). The amount of anesthetic administered in transport conditions should induce a state of sedation, but not general anesthesia, since it is desirable that the fish maintain their normal position through the transport, and that an active opercular movement be also maintained (Iversen et al., 2009). Eugenol, the 
main compound of clove oil, is considered promising in the aquaculture industry because it has low market cost, high efficiency in its use, adequate margin of safety for the fish, and lack of toxicity to humans (Roubach et al., 2005). This anesthetic, which is of recent use in aquaculture practices, has generated beneficial effects after confinement of channel catfish Ictalurus punctatus (Small, 2004), and in the transport of Atlantic salmon (smolt) Salmo salar (Iversen et al., 2009), which resulted in the increase of survival during each procedure, and in reduction of both cortisol and glucose blood levels.

Zeolite, an ion exchange resin, is used in aquaculture in order to remove ammonia in fish production systems, as well as during their storage in tanks or in transport bags (Silapajarn et al., 2006), through sodium ion exchange for ammonia (Kaiser et al., 2006; Singh et al., 2004). The addition of zeolite in the transport of catla Catla catla, roholabeo Labeo rohita, mrigal carp Cirrhinus mrigala (Kaiser et al., 2006; Singh et al., 2004), the Lake Victoria cichlid Haplochromis obliquidens (Kaiser et al., 2006), and guppy Poecilia reticulata (Teo et al., 1989) have been evaluated, and all have reported favorable effects on water quality.

The addition of sodium chloride in water during confinement periods, such as during shipment, has been implemented primarily to help with the electrolyte balance of the fish, because it reduces the osmotic gradient between the internal fluids and the water (Carneiro et al., 2007). The benefits of the use this substance have been demonstrated in tambaqui $\mathrm{Co}^{-}$ lossoma macropomum (Gomes et al., 2003a), matrinxã Brycon amazonicus (Carneiro and Urbinati, 2001), while in other species, such aspirarucu Arapaima gigas (Gomes et al., 2006), and silver catfish Rhamdia quelen (Gomes et al., 1999), the use of salt induced osmoregulatory disturbances and may lead to high mortality during shipment.

The aim of this study is to determine the effect of salt, eugenol and zeolite, as well as mixtures thereof, in the confinement of $A$. triradiatus for periods of 12 and 48 hours on survival, resistance to hyperosmolarity after confinement, blood glucose, and water quality.

\section{Materials and methods}

\section{Experimental fish}

Wild specimens of Ancistrus triradiatus, with marketable size $(9.0 \pm 6.4 \mathrm{~g}$ and $7.0 \pm 1.4 \mathrm{~cm}$ of standard length; $\mathrm{n}=1576$ ) were purchased from local distributors. The fish were acclimated for at least 15 days to laboratory conditions in $40 \mathrm{~L}$ aquaria. Acclimation mortality was $0.78 \%$. The fish were fed once a day with commercial feed with $30 \%$ crude protein. Feeding was suspended 3 days before the experiments were initiated, and was resumed 1 day after the completion of them.

The effect of two confinement times (12 and $48 \mathrm{~h}$ ) was evaluated to simulate frequent transport times occurring in Colombia, and in the processes of exportation. At the beginning of the experiments, fish were weighed (balance Traveler ${ }^{\mathrm{TM}}$ TA3001, OHAUS) and packed in double polyethylene bags $(38 \times 35 \mathrm{~cm}$ to confine them 48 hours, and $29.5 \times 17 \mathrm{~cm}$ to confine them $12 \mathrm{~h}$ ), with $3 \mathrm{~L}$ of water for confinement time of $48 \mathrm{~h}$, and $2 \mathrm{~L}$ for $12 \mathrm{~h}$, utilizing in both cases, a 3:1 volume ratio of oxygen: water. The number of fish and load density per bag were: $31 \mathrm{fish} / \mathrm{bag}$ and $137.5 \mathrm{~g} / \mathrm{L}$ for $12 \mathrm{~h}$ and $27 \mathrm{fish} / \mathrm{bag}$ and $82.3 \mathrm{~g} / \mathrm{L}$ for $48 \mathrm{~h}$. The bags were packed in cardboard boxes and kept under dark conditions.

\section{Substances evaluated}

The inclusion of sodium chloride ( 1 and $2 \mathrm{~g} / \mathrm{L}$, symbolized as S1, and S2 respectively), eugenol (4-allyl2-methoxyphenol) (0.1 and $0.5 \mathrm{mg} / \mathrm{L}$, symbolized as E0.1, and E0.5 respectively), and zeolite ( $7 \mathrm{~g} / \mathrm{L}$ for confinement time of $12 \mathrm{~h}$ and $10 \mathrm{~g} / \mathrm{L}$ for $48 \mathrm{~h}$, symbolized as Zeo) in the water was evaluated for both confinement times. These concentrations were established based on preliminary experiments. For zeolite, the inclusion rate recommended by the manufacturer was also taken into account, which was $1 \mathrm{~g}$ of zeolite per $1.5 \mathrm{mg}$ total ammonia. Mixtures of salt and eugenol (S1-E0.5) and eugenol and zeolite (E0.5-Z) were also evaluated using concentrations of both salt and eugenol that showed the best results when the fish were exposed to these substances separately. The experiments were run in triplicate.

Sodium chloride was purchased in the local market and was a technical grade product. Eugenol was also obtained in the local market and was a pharmaceutical grade product for dental use, and was previously dissolved in ethanol (1:9). Therefore, it was also included a solvent control group exposed to the highest concentration of ethanol that was used in the groups exposed to eugenol, in order to evaluate a possible effect of ethanol. The zeolite, clinoptilolite ProLine ${ }^{\circledR}$, was purchased from Aquatic Eco-Systems, Inc. The control group did not contain any substance added to the water.

\section{Water quality parameters evaluated}

Immediately prior to packing the fish in the polyethylene bags, and also at the end of each experiment, wa- 
ter temperature, dissolved oxygen (oximeterOxi 330i, WTW, Germany), pH, conductivity (multiparameter HI 98129, HANNA Instruments, USA), concentrations of ammonia and nitrite (Spectroquant colorimetric kits, Merck ${ }^{\circledR}$ - Spectronic ${ }^{\circledR} 20$ GENESYS, Spectronic Instruments), hardness (EDTA titrimetric method), and alkalinity (by titration with bromocresol green) (APHA, 1992) were measured. Additionally, non-ionized ammonia concentrations were obtained applying the formulas of Bower and Bidwell (1978), and of Johansson \& Wedborg (1980). The temperature during the experiments was recorded with maximum and minimum thermometers (Sper Scientific), for which two of these thermometers were placed in two bags packed in the same conditions as the fish and kept in boxes with the bags that included the experimental fish. To measure the concentrations of total ammonia and nitrite, the water samples were refrigerated and processed within $24 \mathrm{~h}$.

The water quality parameters at the beginning of the experiments were: dissolved oxygen supersaturation; $\mathrm{pH} 7.35 \pm 0.09$; total ammonia $0.05 \pm 0.01 \mathrm{mg} / \mathrm{L}$; nitrite $0.015 \pm 0.012 \mathrm{mg} / \mathrm{L}$; total hardness $9.13 \pm 3.80 \mathrm{mg} / \mathrm{L}$; and total alkalinity $4.87 \pm 0.50 \mathrm{mg} / \mathrm{L}$. The initial conductivity values of each group are recorded in Table 1.

\section{Blood Glucose Concentration}

The blood glucose concentration was determined from 6 fish in each treatment at 0, 24 and $48 \mathrm{~h}$ after the end of confinement period with a glucose meter

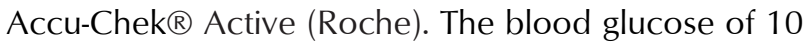
fish was also determined during the acclimation period. This measurement was taken as the basal blood glucose concentration. In order to take the samples of blood from the experimental fish, they were anesthetized with eugenol $(150 \mathrm{mg} / \mathrm{L})$ for 5 minutes.

\section{Test of resistance to conditions of hyperosmolarity}

At the end of the experimental period, a resistance test to hyperosmolarity was performed by the immersion of 20 fish of each treatment in water with $2 \%$ salt ( $\mathrm{NaCl}$, free of iodine and fluorine) and the number of fish which retained the swimming axis for 1 hour was recorded, with readings taken at 5 minute intervals. Once the fish lost their swimming axis, they were taken out in order to recover in an aquarium that was salt-free.

\section{Percentage of mortality}

The mortality rate was recorded at the end of the confinement and also during the following 7 days.
Table 1. Initial water conductivity in the different experimental groups of confinement of Ancistrus triradiatus

\begin{tabular}{|c|c|c|}
\hline $\begin{array}{c}\text { Time of } \\
\text { confinement }\end{array}$ & Group & $\begin{array}{l}\text { Conductivity } \\
\left(\mu \mathrm{S} / \mathrm{cm}^{2}\right)\end{array}$ \\
\hline \multirow[t]{8}{*}{12} & Control & $59 \pm 0$ \\
\hline & S1 & $2253.7 \pm 107.9$ \\
\hline & S2 & $4305 \pm 0$ \\
\hline & E0.1 & $59 \pm 0$ \\
\hline & E0.5 & $67 \pm 0$ \\
\hline & Zeo & $67 \pm 0$ \\
\hline & S1-E0.5 & $2116 \pm 0$ \\
\hline & Z-E0.5 & $64 \pm 0$ \\
\hline \multirow[t]{8}{*}{48} & Control & $59 \pm 0$ \\
\hline & S1 & $2110 \pm 0$ \\
\hline & S2 & $4305 \pm 0$ \\
\hline & E0.1 & $59 \pm 0$ \\
\hline & E0.5 & $67 \pm 0$ \\
\hline & Zeo & $67 \pm 0$ \\
\hline & S1-E0.5 & $2155.3 \pm 2.3$ \\
\hline & Z-E0.5 & $65 \pm 0$ \\
\hline
\end{tabular}

Group S1 = Salt $1 \mathrm{~g} / \mathrm{L}$; group S2= Salt $2 \mathrm{~g} / \mathrm{L}$; group E0.1 = Eugenol 0,1 $\mathrm{mg} / \mathrm{L}$; group E0.5= Eugenol $0.5 \mathrm{mg} / \mathrm{L}$; group Zeo=Zeolite; group S1 E0.5= Salt $1 \mathrm{~g} / \mathrm{L}$ plus Eugenol $0.5 \mathrm{mg} / \mathrm{L}$; group Z-E0.5=Zeolite plus Eugenol $0.5 \mathrm{mg} / \mathrm{L}$. Data expressed as average \pm standard deviations.

\section{Statistical analysis}

The homogeneity of variances was determined with the Levene test $(\mathrm{P}>0.01)$ for blood glucose and water parameters data, and significant differences between groups were established with the ANOVA test followed by the Tukey-Kramer test of multiple comparisons. A logarithmic transformation was done for blood glucose data.

The results of the test of stress resistance were analyzed using a multiple regression test with a linear model with a qualitative predictor for the group, which has $n$ classes that correspond to the number of groups (Kutner et al., 2005).

Mortality results were analyzed by frequency distribution, and the Chi square test of independence was used to establish significant differences between groups and also within each group, as well as between mortality at the end of confinement period and in the following 7 days. 
In all the cases, significant differences were established with $\mathrm{P}<0.05$. The software SAS version 8.05 was used.

\section{Results}

There was no difference between the control and the solvent control group for the different parameters at 12 and 48 hours confinement times (data not showed).

\section{Confinement time of 12 hours}

\section{Water quality parameters}

Dissolved oxygen was maintained at supersaturated conditions in all groups at the end of the experimental period of 12 hours, and the temperature ranged between 26 and $30{ }^{\circ} \mathrm{C}$.

The experiments of the mixtures of salt plus eugenol as well as that of zeolite plus eugenol were performed with concentrations of $1 \mathrm{~g} / \mathrm{L}$ of salt and $0.5 \mathrm{mg} / \mathrm{L}$ of eugenol, based on the results shown in Table 2 .

The $\mathrm{pH}$ in all groups declined at the end of the confinement period relative to the initial $\mathrm{pH}$, and it was significantly lower $(\mathrm{P}<0.05)$ in the group $\mathrm{S} 1-\mathrm{E}$ 0.5. All other groups had the $\mathrm{pH}$ in the 6.0 to 6.4 range, and it was significantly higher $(\mathrm{P}<0.05)$ in the groups E0.5 and Zeo (Table 2). The variation of conductivity was significantly lower $(\mathrm{P}<0.05)$ in the groups $\mathrm{S} 1$ and $\mathrm{S} 1-\mathrm{E}$ 0.5 relative to the rest of the groups (Table 2).

Total ammonia concentrations at the end of this experimental period were in the 4.9 to $6.8 \mathrm{mg} / \mathrm{L}$ range and was significantly lower $(\mathrm{P}<0.05)$ in the group Z-E0.5, and significantly higher $(\mathrm{P}<0.05)$ in the group $\mathrm{S} 1-\mathrm{E}$ 0.5. However, no similar change was observed in the concentration of non-ionized ammonia, which varied in the range of 0.0012 to $0.0031 \mathrm{mg} / \mathrm{L}$, and was significantly higher $(\mathrm{P}<0.05)$ in groups Zeo and E0.5 which showed higher $\mathrm{pH}$ and the concentration of total ammonia was significantly lower $(\mathrm{P}<0.05)$. Additionally, in the group S1-E0.5 the total ammonia concentration was significantly higher in comparison with groups S1 and S0.5 (Table 2).

Nitrite was in the 0.17 to $0.59 \mathrm{mg} / \mathrm{L}$ range, and was significantly lower $(\mathrm{P}<0.05)$ in groups S2 and Z-E0.5. The highest concentration $(\mathrm{P}<0.05)$ was found in the group E0.1 (Table 2).

\section{Blood Glucose Concentration}

Only the group containing $1 \mathrm{~g} /$ Lof salt did not show a significant increase of blood glucose concentration at
Oh after $12 \mathrm{~h}$ of confinement compared to basal blood glucose concentration. After $24 \mathrm{~h}$, all groups returned to the basal concentration (Table 3).

\section{Resistance test to conditions of hyperosmolarity}

The linear regression model between the number of fish that kept their swimming axis(y) and the time of exposure to the saline solution showed an inverse relationship $(\mathrm{P}<0.0001)$ for the two confinement times (Figure 1a).

The model developed was the following:

$y=\beta 0+\left(\beta 1^{*}\right.$ time $)$

$\beta 0$ and $\beta 1$ being significant $(P<0.0001)$.

Control, $y=15.74019+\left(-1.41026^{*}\right.$ time $)$

S1, $y=19.61029+\left(-1.41026^{\star}\right.$ time $)$

S2, $y=20.11029+\left(-1.41026^{*}\right.$ time $)$

E0.1, $y=14.74019+\left(-1.41026^{*}\right.$ time $)$

E0.5, $y=19.36029+\left(-1.41026^{*}\right.$ time $)$

Zeo, $y=18.86029+\left(-1.41026^{\star}\right.$ time $)$

Z-E0.5, $y=17.36029+\left(-1.41026^{*}\right.$ time $)$

S1-E0.5, $y=17.61029+\left(-1.41026^{*}\right.$ time $)$

In the experiment of $12 \mathrm{~h}$, the S2 group showed the greatest stress resistance, and was the only group that showed significant differences with the control group, and also with the group E0.1. The E0.5 group presented significantly higher resistance than the group E0.1. No significant differences were found between the other groups.

\section{Mortality rate}

The group S1-E 0.5 showed significantly higher mortality than all the other groups, except the group E0.1, just after finishing the $12 \mathrm{~h}$ of confinement (Table 4). After7 days post-confinement, the groups S1 and S2 did not show any mortality, which was significantly lower than for the other groups, except the group Zeo. The highest mortality after 7 days post-confinement was found in the groups exposed to mixtures Z-E0.5 and S1-E 0.5. Furthermore, there was a significant increase in mortality during the 7 days post-confinement in the group exposed to the mixture Z-E0.5.

\section{Confinement time of 48 hours}

\section{Water Quality Parameters}

The temperature ranged between 25 and $28{ }^{\circ} \mathrm{C}$. 
Table 2. Parameters of water quality at the end of confinement of Ancistrus triradiatus

\begin{tabular}{|c|c|c|c|c|c|c|}
\hline $\begin{array}{c}\text { Time } \\
\text { confinement }\end{array}$ & Group & pH & $\begin{array}{l}\Delta \text { Conductivity } \\
\qquad\left(\mu \mathrm{S} / \mathrm{cm}^{2}\right)\end{array}$ & $\begin{array}{l}\text { Total ammonia } \\
\qquad(\mathrm{mg} / \mathrm{L})\end{array}$ & $\begin{array}{l}\text { Unionized } \\
\text { ammonia } \\
\left(\times 10^{-3}, \mathrm{mg} / \mathrm{l}\right)\end{array}$ & $\begin{array}{l}\text { Nitrite } \\
(\mathrm{mg} / \mathrm{l})\end{array}$ \\
\hline \multirow[t]{8}{*}{$12 \mathrm{~h}$} & Control & $6.23 \pm 0.07 b$ & $257.3 \pm 16.8 \mathrm{a}$ & $6.0 \pm 0.1 \mathrm{~b}$ & $2.4 \pm 0.3 \mathrm{a} \mathrm{b}$ & $0.44 \pm 0.07 \mathrm{a} \mathrm{b}$ \\
\hline & S1 & $6.06 \pm 0.07 \mathrm{c}$ & $112.0 \pm 3.6 \mathrm{~b}$ & $5.8 \pm 0.1 \mathrm{~b}$ & $1.6 \pm 0.2 \mathrm{c}$ & $0.26 \pm 0.04 \mathrm{ab}$ \\
\hline & $\mathrm{S} 2$ & $6.04 \pm 0.01 \mathrm{c}$ & $212.3 \pm 26.6 \mathrm{a}$ & $5.3 \pm 0.1 \mathrm{c} \mathrm{b}$ & $1.3 \pm 0.1 \mathrm{c}$ & $0.22 \pm 0.04 \mathrm{~b}$ \\
\hline & E0.1 & $6.10 \pm 0.03 \mathrm{~b}, \mathrm{c}$ & $246.3 \pm 25.0 \mathrm{a}$ & $5.4 \pm 0.2 \mathrm{c} \mathrm{b}$ & $1.6 \pm 0.2 \mathrm{c}$ & $0.59 \pm 0.10 \mathrm{a}$ \\
\hline & E0.5 & $6.40 \pm 0.04 \mathrm{a}$ & $266.3 \pm 14.6 \mathrm{a}$ & $5.1 \pm 0.5 \mathrm{c}$ & $3.1 \pm 0.4 \mathrm{a}$ & $0.36 \pm 0.08 \mathrm{a} \mathrm{b}$ \\
\hline & Zeo & $6.42 \pm 0.04 \mathrm{a}$ & $259.7 \pm 18.8 \mathrm{a}$ & $4.9 \pm 0.1 \mathrm{c}$ & $3.1 \pm 0.3 \mathrm{a}$ & $0.39 \pm 0.12 \mathrm{ab}$ \\
\hline & S1-E0.5 & $5.87 \pm 0,01 \mathrm{~d}$ & $135.7 \pm 22.5 \mathrm{~b}$ & $6.8 \pm 0.5 \mathrm{a}$ & $1.2 \pm 0.1 \mathrm{c}$ & $0.33 \pm 0.19 a \mathrm{~b}$ \\
\hline & Z-E0.5 & $6.10 \pm 0.04 \mathrm{~b}, \mathrm{c}$ & $231.3 \pm 34.6 \mathrm{a}$ & $5.5 \pm 0.5 \mathrm{c} \mathrm{b}$ & $1.6 \pm 0.3 b c$ & $0.17 \pm 0.14 b$ \\
\hline \multirow[t]{8}{*}{$48 \mathrm{~h}$} & Control & $6.87 \pm 0.03 \mathrm{a}$ & $386.0 \pm 141.0 \mathrm{a}$ & $10.6 \pm 1.6 \mathrm{ab}$ & $17.5 \pm 3.6 \mathrm{a}$ & $0.26 \pm 0.09 \mathrm{a}$ \\
\hline & $\mathrm{S} 1$ & $6.41 \pm 0.03 b$ & $131.3 \pm 6.7 \mathrm{~b}$ & $8.3 \pm 1.4 \mathrm{~b} \mathrm{c} \mathrm{d}$ & $4.9 \pm 1.0 \mathrm{~b}, \mathrm{c}$ & $0.18 \pm 0.02 \mathrm{a} \mathrm{b}$ \\
\hline & $\mathrm{S} 2$ & $6.83 \pm 0.07 \mathrm{a}$ & $291.7 \pm 65.9 \mathrm{a} \mathrm{b}$ & $9.4 \pm 0.8 \mathrm{a} \mathrm{b} \mathrm{c}$ & $14.9 \pm 1.3 \mathrm{a}$ & $0.11 \pm 0.04 \mathrm{ab}$ \\
\hline & E0.1 & $6.50 \pm 0.07 \mathrm{~b}$ & $242.3 \pm 43.0 \mathrm{a} \mathrm{b}$ & $7.5 \pm 2.1 \mathrm{~b} \mathrm{c} \mathrm{d}$ & $5.6 \pm 0.8 \mathrm{~b}, \mathrm{c}$ & $0.11 \pm 0.01 \mathrm{a} \mathrm{b}$ \\
\hline & E0.5 & $6.72 \pm 0.09 \mathrm{a}$ & $237.7 \pm 44.3 \mathrm{a} \mathrm{b}$ & $5.4 \pm 0.3 \mathrm{~d}, \mathrm{e}$ & $6.7 \pm 1.9 \mathrm{~b}$ & $0.11 \pm 0.01 \mathrm{a} \mathrm{b}$ \\
\hline & Zeo & $6.19 \pm 0.05 \mathrm{c}$ & $197.3 \pm 13.9 \mathrm{~b}$ & $4.0 \pm 0.3 \mathrm{e}$ & $1.5 \pm 0.2 \mathrm{c}$ & $0.08 \pm 0.003 b$ \\
\hline & S1-E0.5 & $6.13 \pm 0.03 c$ & $157.0 \pm 17.1 \mathrm{~b}$ & $12.3 \pm 0.7 \mathrm{a}$ & $4.0 \pm 0.4 \mathrm{~b} \mathrm{c}$ & $0.05 \pm 0.02 b$ \\
\hline & Z-E0.5 & $6.47 \pm 0.04 b$ & $250.3 \pm 10.5 \mathrm{ab}$ & $6.2 \pm 0.8 \mathrm{c} \mathrm{d} \mathrm{e}$ & $4.3 \pm 0.7 b c$ & $0.20 \pm 0.13 a$ \\
\hline
\end{tabular}

Group S1= Salt $1 \mathrm{~g} / \mathrm{L}$; group S2=Salt 2g/L; group E0.1= Eugenol 0,1 mg/L; group E0.5= Eugenol $0.5 \mathrm{mg} /$; group Zeo=Zeolite; group S1-E0.5= Salt $1 \mathrm{~g} / \mathrm{L}$ plus Eugenol $0.5 \mathrm{mg} / \mathrm{l}$; group Z-E0.5= Zeolite plus Eugenol $0.5 \mathrm{mg} / \mathrm{L}$. $\Delta$ conductivity represents the increase of the conductivity between the beginning and end of confinement. Data expressed as average \pm standard deviation. The different letters indicate significant differences between treatments for each time of confinement.

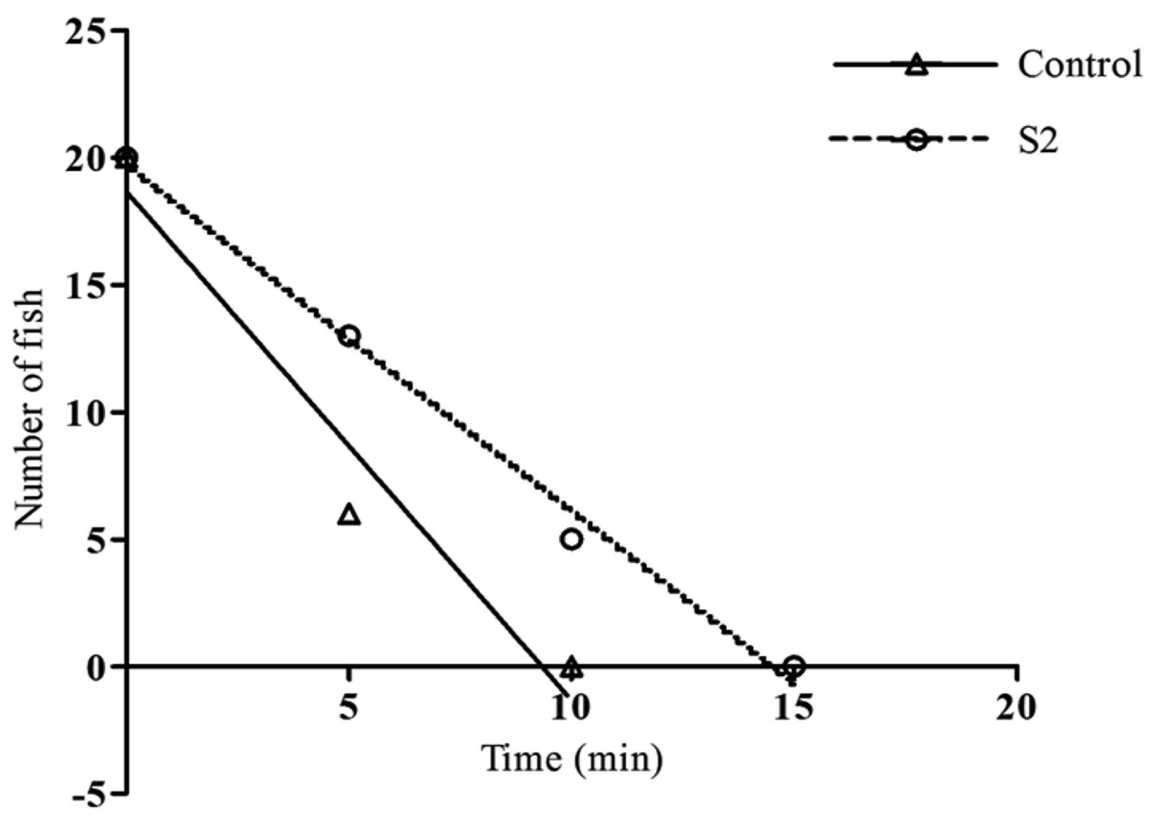

Figure 1a. Model of lineal regression for the resistance test to stress in the experiment of $12 \mathrm{~h}$ for the control group and S2. 
Table 3. Blood glucose concentration ( $\mathrm{mg} / \mathrm{dl}$ ) of Ancistrus triradiatus at different confinement times

\begin{tabular}{|c|c|c|c|c|c|}
\hline \multirow{2}{*}{\multicolumn{2}{|c|}{ Time of confinement }} & \multicolumn{4}{|c|}{ Times of taking blood samples } \\
\hline & & \multirow{2}{*}{$\begin{array}{c}\text { Basal } \\
16.7 \pm 4.3 \mathrm{~A} \\
\end{array}$} & \multirow{2}{*}{$\begin{array}{c}\mathbf{0 ~ h} \\
45 \pm 12.2 \mathrm{~B} \mathrm{a} \mathrm{b}\end{array}$} & \multirow{2}{*}{$\begin{array}{c}\mathbf{2 4} \mathbf{~ h} \\
18.7 \pm 5.5 \mathrm{~A} \mathrm{a} \\
\end{array}$} & \multirow[t]{2}{*}{$48 \mathrm{~h}$} \\
\hline $12 \mathrm{~h}$ & Control & & & & \\
\hline & S1 & $16.7 \pm 4.3 \mathrm{~A}$ & $27.8 \pm 5.6 \mathrm{~A} \mathrm{a}$ & $19.5 \pm 6.2 \mathrm{~A} \mathrm{a}$ & \\
\hline & S2 & $16.7 \pm 4.3 \mathrm{~A}$ & $42.4 \pm 14.5 \mathrm{~B} \mathrm{a} \mathrm{b}$ & $18.8 \pm 5.0 \mathrm{~A} \mathrm{a}$ & \\
\hline & E0.1 & $16.7 \pm 4.3 \mathrm{~A}$ & $34.2 \pm 16.4 \mathrm{~B} \mathrm{a}$ & $13.4 \pm 4.8 \mathrm{~A} \mathrm{a}$ & \\
\hline & E0.5 & $16.7 \pm 4.3 \mathrm{~A}$ & $39.7 \pm 13.2 \mathrm{~B} \mathrm{a} \mathrm{b}$ & $23.2 \pm 4.8 \mathrm{~A} \mathrm{a}$ & \\
\hline & Zeo & $16.7 \pm 4.3 \mathrm{~A}$ & $38.6 \pm 6.3 \mathrm{~B}$ a b & $21.0 \pm 9.6 \mathrm{~A} \mathrm{a}$ & \\
\hline & S1-E0.5 & $16.7 \pm 4.3 \mathrm{~A}$ & $42.0 \pm 5.1 \mathrm{~B} \mathrm{a} \mathrm{b}$ & $19.8 \pm 8.5 \mathrm{~A} \mathrm{a}$ & \\
\hline & Z-E0.5 & $16.7 \pm 4.3 \mathrm{~A}$ & $53.4 \pm 4.8 \mathrm{~B} \mathrm{~b}$ & $15.4 \pm 6.5 \mathrm{~A} \mathrm{a}$ & \\
\hline \multirow[t]{8}{*}{$48 \mathrm{~h}$} & Control & $16.7 \pm 4.3 \mathrm{~A}$ & $24.6 \pm 7.9 \mathrm{~A} \mathrm{a} \mathrm{b}$ & $21.3 \pm 3.7 \mathrm{~A} \mathrm{a}$ & $22.3 \pm 10.2 \mathrm{~A} \mathrm{a}$ \\
\hline & $\mathrm{S} 1$ & $16.7 \pm 4.3 \mathrm{~A}$ & $30.6 \pm 8.0 \mathrm{~A} \mathrm{a} \mathrm{b}$ & $22.3 \pm 4.3 \mathrm{~A} \mathrm{a}$ & $18.8 \pm 4.8 \mathrm{~A} \mathrm{a}$ \\
\hline & S2 & $16.7 \pm 4.3 \mathrm{~A}$ & $18.7 \pm 10.6 \mathrm{~A} \mathrm{a}$ & $20.2 \pm 5.6 \mathrm{~A} \mathrm{a}$ & $20.0 \pm 10.0 \mathrm{~A} \mathrm{a}$ \\
\hline & E0.1 & $16.7 \pm 4.3 \mathrm{~A}$ & $36.0 \pm 16.8 \mathrm{~B} \mathrm{a} \mathrm{b}$ & $25.8 \pm 13.0 \mathrm{~A} \mathrm{a}$ & $27.8 \pm 7.0 \mathrm{~A} \mathrm{a}$ \\
\hline & E0.5 & $16.7 \pm 4.3 \mathrm{~A}$ & $34.4 \pm 6.7 \mathrm{~B}$ a b & $32.0 \pm 4.2 \mathrm{~A} \mathrm{a}$ & $22.8 \pm 7.9 \mathrm{~A} \mathrm{a}$ \\
\hline & Zeo & $16.7 \pm 4.3 \mathrm{~A}$ & $18.0 \pm 4.8 \mathrm{~A} \mathrm{a}$ & $18.5 \pm 7.1 \mathrm{~A} \mathrm{a}$ & $14.0 \pm 8.9 \mathrm{~A} \mathrm{a}$ \\
\hline & S1-E0.5 & $16.7 \pm 4.3 \mathrm{~A}$ & $32.5 \pm 8.0 \mathrm{~A} \mathrm{a} \mathrm{b}$ & $22.8 \pm 11.2 \mathrm{~A} \mathrm{a}$ & $14.2 \pm 6.9 \mathrm{~A} \mathrm{a}$ \\
\hline & Z-E0.5 & $16.7 \pm 4.3 \mathrm{~A}$ & $40.6 \pm 13.4 \mathrm{~B} \mathrm{~b}$ & $25.0 \pm 11.7 \mathrm{~A} \mathrm{a}$ & $18.8 \pm 4.6 \mathrm{~A} \mathrm{a}$ \\
\hline
\end{tabular}

Group S1= Salt $1 \mathrm{~g} / \mathrm{L}$; group S2= Salt 2g/L; group E0.1= Eugenol 0,1 mg/L; group E0.5= Eugenol 0.5 mg/L; group Zeo=Zeolite; group S1-E0.5= Salt $1 \mathrm{~g} / \mathrm{L}$ plus Eugenol $0.5 \mathrm{mg} / \mathrm{L}$; group Z-E0.5= Zeolite plus Eugenol $0.5 \mathrm{mg} / \mathrm{L}$. Blood glucose concentration is expressed in mg/dL. Data expressed as average \pm standard deviation. The different capital letters indicate significant differences between when the samples were taken for each time of confinement. The different lower case letters indicate significant differences between experimental groups for each time of confinement.

The $\mathrm{pH}$ ranged between 6.13 and 6.87 , showing a reduction in each of the groups from the initial values, being significantly lower $(\mathrm{P}<0.05)$ in the groups Zeo and S1-E0.5. The highest $\mathrm{pH}(\mathrm{P}<0.05)$ was found in the control, S2 and E0.5 groups (Table 2). The highest increase of conductivity $(\mathrm{P}<0.05)$ was seen in the control group, while the lowest increase $(P<0.05)$ was found in groups S1, Zeo and S1-E0.5(Table 2).

Total ammonia was in the 4 to $12.3 \mathrm{mg} / \mathrm{L}$ range, and was significantly lower $(\mathrm{P}<0.05)$ in group Zeo. The highest concentrations $(\mathrm{P}<0.05)$ were found in the control, S2 and S1-E0.5 groups (Table 2). Furthermore, the group S1-E0.5 showed significantly higher total ammonia in comparison with groups S1 and S0.5. Unionized ammonia was in the 0.0015 to $0.0175 \mathrm{mg} / \mathrm{L}$ range, and the significantly highest concentrations $(\mathrm{P}<0.05)$ were found in the control and S2 groups. The nitrite concentration was in the 0.05 to $0.26 \mathrm{mg} / \mathrm{L}$ range, with the significantly highest concentration $(\mathrm{P}<0.05)$ in the control group. Significantly lowest concentrations $(\mathrm{P}<0.05)$ were found in the groups Zeo and S1-E0.5 (Table 2).

\section{Blood Glucose Concentration}

The groups E0.1, E0.5 and Z-E0.5 showed a significant increase $(P<0.05)$ on blood glucose at time Oh after confinement, relative to the basal concentration. The lowest blood glucose concentration sat time oh were found in the groups S2 and Zeo. After 24h post-confinement, all groups returned to the basal blood glucose concentration (Table 3).

\section{Test of resistance to conditions of hyperosmolarity}

The linear regression model between the number of fish that kept their swimming axis (y) and time of exposure to the saline solution shows an inverse relationship $(\mathrm{P}<0.0001)$ (Figure 1b).

The model developed was as follows:

$y=\beta_{0}+\left(\beta_{1}{ }^{*}\right.$ time $)$

$\beta_{0}$ and $\beta_{1}$ being significant $(P<0.0001)$.

Control, $y=19.32645+\left(-0.86612^{*}\right.$ time $)$

S1, $y=22.27745+\left(-0.86612^{\star}\right.$ time $)$ 


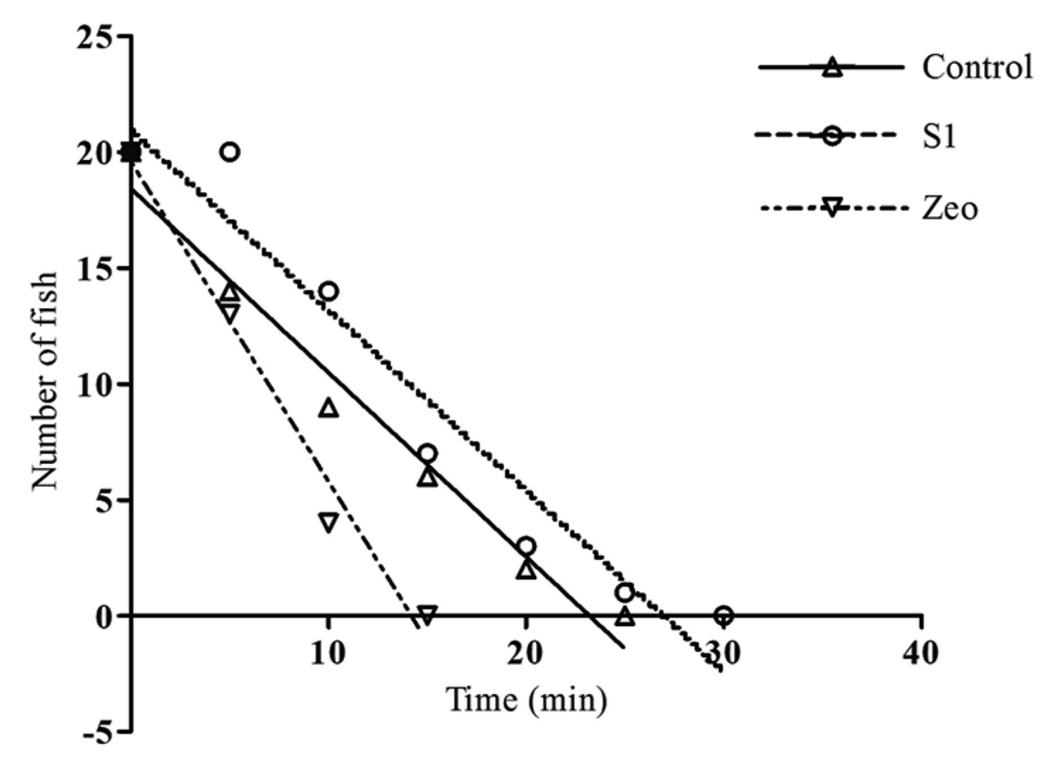

Figure 1b. Model of lineal regression for the resistance test to stress in the experiment of $48 \mathrm{~h}$ for the control group, $\mathrm{S} 1$, and Zeo

S2, $y=18.86116+\left(-0.86612^{*}\right.$ time $)$
E0.1, $y=19.82645+\left(-0.86612^{*}\right.$ time $)$
E0.5, $y=18.46116+\left(-0.86612^{*}\right.$ time $)$
Zeo, $y=15.74587+\left(-0.86612^{*}\right.$ time $)$
Z-E0.5, $y=15.49587+\left(-0.86612^{\star}\right.$ time $)$
S1-E0.5, $y=21.56317+\left(-0.86612^{*}\right.$ time $)$

Groups S1 and S1-E0.5 had the highest resistance to stress, while the lowest resistance was shown in the groups Zeo and Z-E0.5 (Figure 1b).

\section{Mortality rate}

There were no significant differences in mortality right after finishing the confinement period. However, there was a significant increase on mortality in the S2 group for the following 7 days which resulted insignificantly higher mortality rate compared to the other groups.

\section{Discussion}

\section{Water quality parameters}

The reduction in $\mathrm{pH}$ values obtained at the end of confinement period compared to the initial value is due to the production of $\mathrm{CO}_{2}$, a product of respiration. In general, $\mathrm{pH}$ values recorded in all groups are below the range recorded in habitats of this species, this being approximately 6.5 to 7.5 (Ramírez-Duarte et al., 2009). Although this reduction in $\mathrm{pH}$ values lowers the concentration of non-ionized ammonia in the water, it also has deleterious effects, such as, decreased oxygen carrying capacity of the blood (Berka, 1986). So it is recommended that buffer substances be used in the water as it has been suggested by other authors (Lim et al., 2003).

The increase in the water conductivity of the water at the end of the experiments is explained by the net loss of electrolytes from the blood, a process favored by the increase in gill permeability, caused by the increased secretion of catecholamines and cortisol as part of the primary stress response in fish (Wendelaar-Bonga, 1997). In both experiments (12 and 48h), the lowest increases of conductivity in groups S1 and S1-E 0.5 can be explained by the reduced osmotic gradient between the plasma and the water that reduces the loss of plasma electrolytes (Carneiro et al., 2007).

In the experiment of $48 \mathrm{~h}$, the significantly lower change of conductivity and blood glucose concentration in group Zeo may indicate that the adsorptive action of the zeolite on ammonia mitigates or prevents the ammonia-induced ionoregulatory disturbances (Silapajarn et al., 2006). Similar to the results obtained for Nile tilapia Oreochromis niloticus (Oliveira et al., 2009), the addition of increasing amounts of salt and eugenol did not reduce total ammonia at the end of 12 hour experiment. The addition of eugenol to transport water of Haplochromis obliquidens (Kaiser et al., 2006) and matrinxã (Inoue et al., 2005) also did not reduce total ammonia concentration.

Even though significant differences were found in the concentration of non-ionized ammonia between 
Table 4. Mortality (\%) of Ancistrus triradiatus at the end of confinement and at the end of the following 7 days

\begin{tabular}{|c|c|c|c|}
\hline \multicolumn{2}{|c|}{ Time of confinement } & Day 0 & $\begin{array}{c}\text { Accumulated to the } \\
\text { 7th day }\end{array}$ \\
\hline $12 \mathrm{~h}$ & Control & $3.2 \mathrm{~A} \mathrm{a} \mathrm{b}$ & $4.3 \mathrm{~A} \mathrm{~b} \mathrm{c}$ \\
\hline & $\mathrm{S} 1$ & $0 \mathrm{~A} \mathrm{a}$ & $0.0 \mathrm{~A} \mathrm{a}$ \\
\hline & S2 & $0 \mathrm{~A} \mathrm{a}$ & $0.0 \mathrm{~A} \mathrm{a}$ \\
\hline & E0.1 & $4.3 \mathrm{~A} \mathrm{a} \mathrm{b}$ & $6.5 \mathrm{~A} \mathrm{~b} \mathrm{c}$ \\
\hline & E0.5 & $0 \mathrm{~A} \mathrm{a}$ & $4.8 \mathrm{~A} \mathrm{~b} \mathrm{c}$ \\
\hline & Zeo & $0 \mathrm{~A} \mathrm{a}$ & $2.2 \mathrm{~A} \mathrm{a} \mathrm{b}$ \\
\hline & Z-E0.5 & $1.1 \mathrm{~A} \mathrm{a}$ & $9.7 \mathrm{~B} \mathrm{c}$ \\
\hline & S1-E0.5 & $7.5 \mathrm{~A} \mathrm{~b}$ & $10.8 \mathrm{~A} \mathrm{C}$ \\
\hline & Control & $3.7 \mathrm{~A} \mathrm{a}$ & $3.7 \mathrm{~A} \mathrm{a}$ \\
\hline & S1 & $0 \mathrm{~A} \mathrm{a}$ & $0 \mathrm{~A} \mathrm{a}$ \\
\hline & S2 & $0 \mathrm{~A} \mathrm{a}$ & $16 \mathrm{~B} \mathrm{~b}$ \\
\hline & E0.1 & $0 \mathrm{~A} \mathrm{a}$ & $1.2 \mathrm{~A} \mathrm{a}$ \\
\hline & E0.5 & $1.2 \mathrm{~A} \mathrm{a}$ & $1.2 \mathrm{~A} \mathrm{a}$ \\
\hline & Zeo & $1.2 \mathrm{~A} \mathrm{a}$ & $3.7 \mathrm{~A} \mathrm{a}$ \\
\hline & S1-E0.5 & $1.2 \mathrm{~A} \mathrm{a}$ & $1.2 \mathrm{~A} \mathrm{a}$ \\
\hline & Z-E0.5 & $1.2 \mathrm{~A} \mathrm{a}$ & $2.5 \mathrm{~A} \mathrm{a}$ \\
\hline & &
\end{tabular}

Group S1= Salt $1 \mathrm{~g} / \mathrm{L}$; group S2= Salt 2g/L; group E0.1= Eugenol 0,1 mg/L; group E0.5= Eugenol $0.5 \mathrm{mg} / \mathrm{L}$; group Zeo=Zeolite; group S1-E0.5= Salt $1 \mathrm{~g} / \mathrm{L}$ plus Eugenol $0.5 \mathrm{mg} / \mathrm{L}$; group Z-E0.5=Zeolite plus Eugenol $0.5 \mathrm{mg} / \mathrm{L}$. The different capital letters indicate significant differences between days for the same experimental group.The different lower case letters indicate significant differences between experimental groups for each time of confinement.

groups in both experiments (12 and $48 \mathrm{~h}$ ), in all cases (Table 2) they were well below the range of values of $\mathrm{LC}_{50}$ at $96 \mathrm{~h}$ reported for teleosts $(\geq 0.34 \mathrm{mg} / \mathrm{L})$ for $\mathrm{pH}$ values between 6 and 8.2 (Abbas, 2006; Miron et al., 2008; Rodrigues et al., 2007).

The concentrations of nitrite in the experiment of $12 \mathrm{~h}$ were found near and above concentrations reported as lethal to other fish species $(0.25 \mathrm{mg} / \mathrm{L}$ at $96 \mathrm{~h}$ in Oncorhynchus mykiss) (Russo et al., 1981). A similar situation was found in the experiment of $48 \mathrm{~h}$, except for groups exposed to zeolite (Zeo) and S1-E0.5. In the case of the zeolite group, it may be lower due to significantly lower concentrations of total ammonia. However, the mechanism is unknown by which in the group salt plus eugenol the concentration of nitrite was significantly lower, even when the same group presented the highest concentration of total ammonia. Nitrite is produced by bacterial oxidation of ammonia, and from the aerobic decomposition of organic matter, and it accumulates as nitrite generation exceeds the rate of oxidation of nitrite to nitrate (Wedemeyer,
1996). However, no relationship was found between nitrite concentration and mortality.

\section{Concentration of blood glucose}

The rise of concentration of catecholamines and cortisol in blood induces an increase in blood glucose, so this parameter is used as an indicator of stress when the fish are exposed to stressful events (Carneiro and Urbinati, 2001; Gomes et al., 2003b; Wendelaar-Bonga, 1997).

In this study the beneficial effect of adding salt to water in both experiments (12 and $48 \mathrm{~h}$ ) is also reflected in the results of the glucose concentration $12 \mathrm{~h}$ experiment (Table 3), where the group S1 was the only group that did not increase significantly the blood glucose right after the confinement period finished (time Oh) compared to the basal blood glucose concentration, indicating less energy expenditure imposed by the reduced loss of electrolytes into the blood. 
The addition of salt has been linked to decreased secretion of cortisol and lower levels of glucose during and after transport in tambaqui Colossoma macropomum exposed to $8 \mathrm{~g} / \mathrm{L}$ (Gomes et al., 2003a), matrinxã to $6 \mathrm{~g} / \mathrm{L}$ (Carneiro and Urbinati, 2001) and pejerrey (Odontesthes bonariensis) exposed to 3-5 g/L (Tsuzuki et al., 2001). Therefore, reduction of stress may be reflected in low gill permeability, leading to lower ion loss through gill epithelium.

Eugenol at 0.1 and $0.5 \mathrm{mg} / \mathrm{L}$ (E0.1 and E0.5 respectively) did not reduce fish stress during the two confinement times. In contrast to these results, 2 to $5 \mathrm{mg} / \mathrm{L}$ eugenol in Nile tilapia (Oliveira et al., 2009) and 5 $\mathrm{mg} / \mathrm{L}$ in matrinxã (Inoue et al., 2005) were reported as useful for mitigating the stress response as reflected in low blood glucose levels at the end of transport. In preliminary trials with $A$. triradiatus, 5 and $10 \mathrm{mg} / \mathrm{L}$ eugenol caused loss of the swimming axis and severe reduction of opercular movements within one hour of exposure, and at $10 \mathrm{mg} / \mathrm{L}$ the fish did not recover after one hour of exposure and died (unpublished data). It is recommended that fish maintain their normal position within the transport containers, or bags, and also maintain an active opercular movement (Iversen et al., 2009).

\section{Test of resistance to conditions of hyperosmolarity}

Exposure to high concentrations of salt has been suggested as a resistance test to stress, where a high resistance indicates increased survival of fish when subjected to stressful conditions (Lim et al., 2003). Stress increases gill permeability and leads to changes in plasma electrolyte concentrations in hyposmotic or hyperosmotic environments (Carneiro et al., 2007). In this experiment, it was found that the groups exposed to salt $2 \mathrm{~g} / \mathrm{L}$ in the experiment of $12 \mathrm{~h}$, and $1 \mathrm{~g} / \mathrm{L}$ of salt in the experiment of $48 \mathrm{~h}$, were the only groups that showed a significant increase in resistance compared with the control group, indicating less impairment of gill permeability, which gives it greater capacity to conserve hydro-electrolytic balance to stressors, and, therefore, greater chance of survival (Carneiro et al., 2007).

Eugenol at 0.1 and $0.5 \mathrm{mg} / \mathrm{L}$ (E0.1 and E0.5 respectively) and the mixtures S1-E0.5 and Z-E0.5 did not improve $(\mathrm{P}<0.05)$ resistance to stress compared with the control group.

\section{Percentage of mortality}

The absence of mortality in groups exposed to 1 and $2 \mathrm{~g} / \mathrm{L} \mathrm{NaCl}$ in the $12 \mathrm{~h}$ experiment and $\mathrm{S} 1$ group in the experiment of $48 \mathrm{~h}$ shows the beneficial effects of sodium chloride by reducing the osmotic gradient between the water and blood, alleviating the stress, and increasing resistance to conditions of hyperosmolarity. The absence of mortality in these groups is notable because it avoids deterioration of water quality caused by dead fish.

The $16 \%$ mortality registered for the S2 group in the experiment of $48 \mathrm{~h}$ the following 7 days after finishing the confinement period indicates that the concentration of $2 \mathrm{~g} / \mathrm{L}$ of salt is not suitable for prolonged exposure in the confinement of $A$. triradiatus. Gomes et al. $(1999,2006)$ reported that exposure of jundiá to $6 \mathrm{~g} / \mathrm{L}$ of salt, and tambaqui to 1, 2, and $3 \mathrm{~g} / \mathrm{L}$, caused mortality after $12 \mathrm{~h}$ and $24 \mathrm{~h}$, respectively. Gomes et al. (2006) also reported that exposure of pirarucú to concentrations between 1 and $5 \mathrm{~g} / \mathrm{L}$ induced osmoregulatory disturbances and did not alleviate the stress during transport. Similarly, Pavlidis et al. (2003) did not report beneficial effects from the addition of salt on the survival of red porgy, Pagrus pagrus. The significant increase in mortality after 7 days in the group exposed to $2 \mathrm{~g} / \mathrm{L}$ of salt agrees with the recommendation of Lim et al. (2003) to monitor mortality up to 7 days after transport due to the effects of stress in the medium term.

There was not a beneficial effect of eugenol and the mixtures S1-E0.5 and Z-E0.5 on fish survival.

\section{Conclusions}

The use of 1 to $2 \mathrm{~g} / \mathrm{L}$ sodium chloridein $12 \mathrm{~h}$ confinement, and of $1 \mathrm{~g} / \mathrm{L}$ in $48 \mathrm{~h}$ confinement, increases resistance to stress, and reduces the mortality of $A$. triradiatus. The use of eugenol or zeolite did nor reduce the stress response nor reduce mortality. The combinations of salt plus eugenol and zeolite plus eugenol are not recommended because they can increase mortality.

\section{Acknowledgements}

This study was developed under the project "Construction of the first epidemiological map of ornamental fish diseases in Colombia",contract No. 057-2007U4448387-07, funded by the Ministry of Agriculture and Rural Development of Colombia, as a result of a national contest co-finance research programs, technological development, and innovation for the agricultural sector by means of productive chains.

The authors express their gratitude to the young members of Research Group on Health of Aquatic 
Organisms of the Universidad de los Llanos that collaborated in the development of the experiments.

\section{References}

Abbas $\mathrm{HH}$. Acute toxicity of ammonia to common carp fingerlings (Cyprinus carpio) at different pH levels. Pak J Biol Sci, 2006; 9 (12): 2215-2221.

APHA - American Public Health Association. 1992. Standard methods for the examination of water and wastewater, $18^{\text {th }}$ edition, Washington.

Barton BA, Bollig $\mathrm{H}$, Hauskins BL, Jansen CR. Juvenile pallid (Scaphirhynchus albus) and hybrid pallid×shovelnose (S. albus xplatorynchus) sturgeons exhibit low physiological responses to acute handling and severe confinement. Comp Biochem Physiol A, 2000; 126(1): 125-134.

Berka R. 1986. The transport of live fish.A review.EIFAC technical paper 48, $52 \mathrm{pp}$.

Bower C, Bidwell J. Ionization of ammonia in sea water effects of temperature, $\mathrm{pH}$, and salinity on Salmo salarL. I Fish Res Board Can, 1978; 35(7): 1012-1016.

Carneiro PCF, Urbinati EC. Salt as a stress response mitigator of matrinxã, Brycon cephalus (Günther), during transport. Aquaculture Research, 2001; 32(4): 297-304.

Carneiro P CF, Urbinati EC, Bendhack F. 2007. Osmoregulation and fish transportation. En: Baldisserotto B, Mancera JM, Kapoor BG (Editores.). Fish Osmoregulation. Science Publishers, Enfield, p. 235-248.

Collazos-Lasso LF, Arias-Castellanos JA. Estimulación a la maduración final y el desove de Ancistrus triradiatus. Orinoquia, 2009; 13(1): 14-19.

Golombieski JI, Silva L VF, Baldisserotto B, Da Silva J HS. Transport of silver catfish (Rhamdia quelen) fingerlings at different times, load densities, and temperatures. Aquaculture, 2003; 216(1-4): 95-102.

Gomes LC, Golombieski JI, Chippari-Gomes AR, Baldisserotto B. Effect of salt in the water for transport on survival and on $\mathrm{Na}^{+}$and $\mathrm{K}^{+}$body levels of silver catfish, Rhamdia que len, fingerlings. J Appl Aquaculture, 1999; 9(4): 1-9. J Aplli Aquac,

Gomes LC, Araujo-Lima CARM, Roubach R, Urbinati EC. Avaliação dos efeitos da adição de sal e da densidade no transporte de tambaqui. Pesq Agropec Bras, 2003a; 38(2): 283-290.

Gomes LC, Roubach R, Araujo-Lima CARM, Chippari-Gomes AR, Lopes NP, Urbinati EC. Effect of fish density during transportation on stress and mortality of juvenile tambaqui Colossoma macropomum. J World Aquacult Soc, 2003b; 34(1): 76-84.

Gomes LC, Chagas EC, Brinn RP, Roubach R, Coppati CE, Baldisserotto $\mathrm{B}$. Use of salt during transportation of air breathing pirarucu juveniles (Arapaima gigas) in plastic bags. Aquaculture, 2006; 256(1-4): 521-528.

Gomes LC, Brinn RP, Marcon JL, Dantas LA, Brandão FR, Abreu JSD, Lemos PEM, Mccomb DM, Baldisserotto B. Benefits of using the probiotic Efinol ${ }^{\circledR} \mathrm{L}$ during transportation of cardinal tetra,
Paracheirodon axelrodi (Schultz), in the Amazon. Aquacult Res, 2009; 40(2): 157-165

Hoskonen P, Pirhonen J. Short communication. The effect of clove oil sedation on oxygen consumption of six temperate - zone fish species. Aquacult Res, 2004; 35(10): 1002-1005.

Inoue KALA, Afonso LOB, Iwama GK, Moraes G. Effects of clove oil on the stress response of matrinxã (Brycon cephalus) subjected to transport. Acta Amaz, 2005; 35 (2): 289-295.

Iversen M, Eliassen RA, Finstad B. Potential benefit of clove oil sedation on animal welfare during salmon smolt, Salmo salar L. transport and transfer to sea. Aquacult Res, 2009; 40(2): 233-241.

Johansson $\mathrm{O}$, Wedborg $\mathrm{M}$. The ammonia-ammonium equilibrium in the seawater at temperature between 5 and $25{ }^{\circ} \mathrm{C}$. I Solution Chem, 1980; 9(1): 37- 44.

Kaiser H, Brill G, Cahill J, Collett P, Czypionka K, Green A, Orr K, Pattrick P, Scheepers R, Stoiner T, Whitehead MA, Yearsley R. Testing clove oil as an anaesthetic for long-distance transport of live fish: the case of the Lake Victoria cichlid Haplochromis obliquidens. J Appl Ichthyol, 2006; 22(6): 510-514.

Kutner M, NachtsheimC, Neter J, Li W. 2005. Applied linear statistical models. Irwin, Boston, McGraw-Hill.

Lim LC, Dhert P, Sorgeloos P. Recent developments and improvements in ornamental fish packaging systems for air transport. Aquacult Res, 2003; 34(11): 923-935.

Mancera-Rodríguez NJ, Álvarez-LeónR. Comercio de peces ornamentales en Colombia. Acta Biol Colomb, 2008; 13(1): 23-52.

MADR - Ministerio de Agricultura y Desarrollo Rural y CCl- Corporación Colombiana Internacional. 2010. Pesca y Acuicultura Colombia 2009 "Informe técnico regional de cuencas del Orinoco y Amazonas". Corporación Colombiana Internacional. 71 p.

Miron DS, Moraes B, Becker AG, Crestani M, Spanevello R, Loro VL, Baldisserotto, B. Ammonia and $\mathrm{pH}$ effects on some metabolic parameters and gill histology of silver catfish, Rhamdia quelen (Heptapteridae). Aquaculture, 2008; 277(3-4): 192-196.

Oliveira JR, Laurindo Do Carmo J, Calvalcanti Oliveira KK, Soares Figueredo MDC. Cloreto de sódio, benzocaína e óleo de cravo da índia na água de transporte de tilápida do nilo. R Bras Zootec, 2009; 38(7):1163-1169.

Pan C-H, Chien Y.-H, Wang Y-J. The antioxidant capacity response to hypoxia stress during transportation of characins Hyphessobrycon callistus(Boulenger) fed diets supplemented with carotenoids. Aquacult Res, 2010; 41(7): 973-981.

Pavlidis M, Angellotti L, Papandroulakis N, Divanach P. Evaluation of transportation procedures on water quality and fry performance in red porgy (Pagrus pagrus) fry. Aquaculture, 2003; 218(14): $187-202$.

PramodPK, Ramachandran A, Sajeevan TP, Thampy S, Pai SS. Comparative efficacy of MS-222 and benzocaine as anaesthetics under simulated transport conditions of a tropical ornamental fish Puntius filamentosus (Valenciennes). Aquacult Res, 2010; 41(2): 309-314. 
Ramírez-Duarte W, Parada S, Martínez N, Eslava-Mocha P, Figueroa J, Iregui C. 2009. Manejo de peces de la familia Loridariidae en el municipio de Acacías, Meta: monitoreo desde la captura hasta la comercialización (Reporte preliminar). In: Memorias XV Jornada de Acuicultura, Instituto de Acuicultura de los Llanos, Universidad de los Llanos (ed.). Villavicencio, Meta (Colombia). p 58-65.

Roubach R, Gomes LC, Fonseca FAL, Val AL. Eugenol as an efficacious anaesthetic for tambaqui, Colossoma macropomum (Cuvier). Aquacult Res, 2005; 36(11): 1056-1061.

Rodrigues RV, Schwarz MH, Delbos BC, Sampaio LA. Acute toxicity and sublethal effects of ammonia and nitrite for juvenile cobia Rachycentron canadum. Aquaculture, 2007; 271(1-4):553-557.

Russo RC, Thurston RV, Emerson K. Acute toxicity of nitrite to rainbow trout (Salmo gairdneri): effects of $\mathrm{pH}$, nitrite species, and anion species. Can J Fish Aquat Sci, 1981; 38(4): 387-397.

Silapajarn O, Silapajarn K, Boyd CE. Evaluation of zeolite products used for aquaculture in Thailand. J World Aquac Soc, 2006; 37(1): 136-138.
Singh RK, Vartak VR, Balange AK, Ghughuskar MM. Water quality management during transportation of fry of Indian major carps, Catla catla (Hamilton), Labeo rohita (Hamilton) and Cirrhinus mrigala (Hamilton). Aquaculture, 2004; 235(1-4): 297-302.

Teo LH, Chen TW, Lee BH. Packaging of the guppy, Poecilia reticulata, for air transport in a closed system. Aquaculture, 1989; 78(3-4): 321-332.

Tsuzuki MY, Ogawa K, Strüssmann CA, Maita M, Takashima F. Physiological responses during stress and subsequent recovery at different salinities in adult pejerrey Odontesthes bonariensis. Aquaculture, 2001; 200(3-4): 349-362.

Urbinati EC, De Abreu JS, Da Silva Camargo AC, Landinez Parra MA. Loading and transport stress of juvenile matrinxã (Brycon cephalus, Characidae) at various densities. Aquaculture, 2004; 229(1-4): 389-400. 